\title{
Consuming Pleasures
}


THE ARTS AND INTELLECTUAL LIFE IN MODERN AMERICA

\author{
Casey Nelson Blake, Series Editor
}

Volumes in the series explore questions at the intersection of the history of expressive culture and the history of ideas in modern America. The series is meant as a bold intervention in two fields of cultural inquiry. It challenges scholars in American studies and cultural studies to move beyond sociological categories of analysis to consider the ideas that have informed and given form to artistic expression-whether architecture and the visual arts or music, dance, theater, and literature. The series also expands the domain of intellectual history by examining how artistic works, and aesthetic experience more generally, participate in the discussion of truth and value, civic purpose and personal meaning that have engaged scholars since the late nineteenth century.

Advisory Board: Steven Conn, Lynn Garafola, Charles McGovern, Angela L. Miller, Penny M. Von Eschen, David M. Scobey, and Richard Cándida Smith 


\title{
CONSUMING PLEASURES
}

Intellectuals and Popular Culture in the Postwar World

\section{Daniel Horowitz}

\author{
$\overline{\text { PENN }}$ \\ UNIVERSITY OF PENNSYLVANIA PRESS \\ P H I L A D E L P H I A
}


Copyright (c) 2012 University of Pennsylvania Press

All rights reserved. Except for brief quotations used for purposes of review or scholarly citation, none of this book may be reproduced in any form by any means without written permission from the publisher.

\author{
Published by \\ University of Pennsylvania Press \\ Philadelphia, Pennsylvania 19104-4112 \\ www.upenn.edu/pennpress
}

Printed in the United States of America on acid-free paper

$\begin{array}{llllllllll}10 & 9 & 8 & 7 & 6 & 5 & 4 & 3 & 2 & 1\end{array}$

Library of Congress Cataloging-in-Publication Data

Horowitz, Daniel, 1938-

Consuming pleasures : intellectuals and popular culture in the postwar world / Daniel Horowitz. - 1st ed.

p. cm. - (The arts and intellectual life in modern America)

Includes bibliographical references and index.

ISBN 978-0-8122-4395-6 (hardcover : alk. paper)

1. Popular culture-Economic aspects-United States-2oth century. 2. Popular culture-Economic aspects-Europe-2oth century. 3. Consumption (Economics) United States-Psychological aspects—2oth century. 4. Consumption (Economics) Europe-Psychological aspects—2oth century. 5. Intellectuals-United StatesAttitudes-History-2oth century. 6. Intellectuals-Europe-Attitudes-History-2oth century. I. Title. II. Series: Arts and intellectual life in modern America.

E169.12.H675 2012

$306-\mathrm{dc} 23$ 
To some of the colleagues and friends

who have sustained me over the years:

Bob Abzug, Ellen DuBois, Judy Smith, Char Miller,

Lynn Dumenil, Wendy Kline

And to Helen Horowitz

First, last, and always 
This page intentionally left blank 